$\begin{array}{ll}\text { Volume } & : 04 \\ \text { Nomor } & : 02 \\ \text { Bulan } & : \text { Mei } \\ \text { Tahun } & : 2018 \\ \text { http } & : \text { //ejurnal.pps.ung.ac.id/index.php/AKSARA/index }\end{array}$

\title{
Analisis Titik Pulang Pokok Pada Usahatani Padi Sawah Di Desa Kospa Duwata Karya Kecamatan Masama Kabupaten Banggai
}

\author{
Ismail Djamaluddin \& I Wayan Widia \\ Fakultas Pertanian, Universitas Tompotika Luwuk \\ Email : ismaildjamal.id@gmail.com
}

\begin{abstract}
ABSTRAK
Tujuan Penelitian ini adalah untuk mengetahui besar total biaya produksi, besarnya produksi fisik, harga jual serta besarnya penerimaan yang diperoleh para petani dalam usahatani padi sawah di Desa Kospa Duwata Karya sehingga usahataninya mencapai titik pulang pokok atau dengan kata lain usahataninya tidak mengalami kerugian maupun memperoleh laba.

Penentuan Populasi dengan menggunakan Metode sampel acak bertingkat (Stratifikasi Random Sampling) yaitu Dari populasi petani (Responden) sebanyak 255 orang (KK) yang di tatapkan menjadi sampel sebanyak 26 orang petani atau 10 $\%$, Dengan pertimbangan untuk mewakili populasi petani yang berusahatani Padi Sawah (Oryza sativa. L) di Desa Kospa Duwata Karya

Berdasarkan hasil penelitian dan pembahasan Volume penjualan pada titik pulang pokok untuk produksi fisik Padi Sawah di Desa Kospa Duwata Karya adalah sejumlah 81,67 kg, dengan harga jual Rp. 5.909,- per kg.

Hasil perhitungan menunjukkan, bahwa pada rata-rata lahan usahatani Padi Sawah seluas 1,10 ha, para petani responden akan mencapai titik pulang pokok atau tidak untung dan tidak rugi, jika penerimaan yang diperoleh mencapai $\mathrm{Rp}$. 482.578 ,- per MT, atau produksi rata-rata mencapai $81,67 \mathrm{~kg}$.

Kata kunci : Titik pulang pokok, usahatani, padi sawah
\end{abstract}

\section{PENDAHULUAN}

Bangsa Indonesia dan bahkan sebagian besar penduduk dimuka bumi menggunakan beras sebagai bahan pokok dalam usaha mempertahankan kelangsungan hidupnya. Beras adalah buah padi, berasal dari tumbuh-tumbuhan golongan rerumputan yang mengandung gii dan penguat yang cukup bagi tubuh manusia, oleh karena itu padi juga merupakan sumber makanan energi.

Beras menduduki posisi penting dalam susunan menu rakyat Indonesia. Sebagai Bahan makanan, beras sangat berguna bagi tubuh manusia karena mengandung karbohidrat, lemak dan protein sebagai sumber energi.

Kabupaten Banggai tanaman Padi Sawah (Oryza sativa. L) ditanam di lahan sawah berpengairan dan sawah tadah hujan serta di ladang (Padi gogo). Untuk memperbaiki teknologi produksi Padi Sawah (Oryza sativa. L) di Kabupaten Banggai telah dilakukan berbagai upaya dengan teknologi pemilihan varietas dan penyiapan benih unggul, pengolahan lahan yang baik, waktu dan cara tanam yang tepat, pemupukan, pengendalian hama penyakit dan gulma, pelaksanaan panen serta penanganan pasca panen yang baik. Berikut adalah data luas areal produksi dan produktivitas Padi Sawah (Oryza sativa. L) di Kabupaten Banggai . 
Tabel 1. Luas Panen, Produksi dan Produktivitas Tanaman Padi Sawah (Oryza sativa. L) di Kabupaten Banggai selama 4 Tahun (2008-2011)

\begin{tabular}{cccc}
\hline Tahun & $\begin{array}{c}\text { Luas Panen } \\
(\mathrm{Ha})\end{array}$ & $\begin{array}{c}\text { Produksi } \\
\text { (Ton) }\end{array}$ & $\begin{array}{c}\text { Produktivitas } \\
\text { (Ton / Ha) }\end{array}$ \\
\hline 2008 & 33.165 & 135.530 & 4,09 \\
2009 & 34.120 & 143.220 & 4,20 \\
2010 & 34.132 & 145.350 & 4,26 \\
2011 & 38.610 & 180.100 & 4,66 \\
\hline Jumlah & 140.027 & 604.200 & 17,21 \\
\hline Rata-rata & $35.006,75$ & 151.050 & 4,30 \\
\hline
\end{tabular}

Sumber Data : BPS Kabupaten Banggai, 2012.

Tabel 1 dapat di lihat bahwa Kabupaten Banggai merupakan salah satu sentra penghasil Padi Sawah (Oryza sativa. L) di Kabupaten Banggai terlihat jelas bahwa dari tahun ke tahun produksi dan produktivtas tanaman Padi terus meningkat dimana pada tahun 2008 dengan luas panen 33.165 ha dan produksi 135.530 Ton menghasilkan produktivitas 4,09 ton/ha dan pada tahun 2011 produksi dan produktivitas tanaman padi sawah meningkat menjadi 180.100 ton dan 4,66 ton/ha, untuk melihat jumlah Produksi dan Produktivitas Tanaman Padi Sawah di Beberapa Kecamatan di Kabupaten Banggai terdapat pada Tabel 2 berikut ini.

Tabel 2. Luas Panen, Produksi dan Produktivitas Tanaman Padi Sawah di beberapa Kecamatan Kabupaten Banggai selama Tahun 2012.

\begin{tabular}{lccc}
\hline Kecamatan & $\begin{array}{c}\text { Luas Panen } \\
(\mathrm{Ha})\end{array}$ & $\begin{array}{c}\text { Produksi } \\
\text { ( Ton })\end{array}$ & $\begin{array}{c}\text { Produktivitas } \\
\text { ( Ton / Ha ) }\end{array}$ \\
\hline Toili Barat & 7.133 & 31.326 & 4,60 \\
Toili & 10.599 & 47.377 & 4,75 \\
Batui & 2.095 & 10.370 & 4,95 \\
Kintom & - & - & - \\
Luwuk & - & - & - \\
Luwuk Timur & 958 & 4.503 & 4,70 \\
Masama & 5.384 & 26.602 & 4,95 \\
Lamala & 432 & 19.44 & 4,50 \\
Balantak & - & - & - \\
Bualemo & 1.310 & 6.092 & 4,65 \\
Pagimana & 122 & 549 & 4,50 \\
Bunta & 32 & 146 & 4.55 \\
Nuhon & 1.020 & 4.743 & 4.65 \\
Moilong & 3.740 & 18.139 & 4,85 \\
Batui Selatan & 4.532 & 22.433 & 4,95 \\
Balantak Selatan & 18 & 72 & 4,00 \\
Lobu & - & - & - \\
Simpang Raya & 1.235 & 5.805 & 4,70 \\
\hline \multicolumn{1}{c}{ Jumlah } & 38.610 & 180.100 & 46,65 \\
\hline
\end{tabular}




\begin{tabular}{rrrr}
\hline Rata-rata & 2.145 & $1.005,56$ & 2,59 \\
\hline
\end{tabular}

Sumber Data : BPS Kabupaten Banggai, 2012.

Tabel 2 dapat di lihat bahwa Kecamatan Masama merupakan salah satu sentra penghasil Padi Sawah (Oryza sativa. L) di Kabupaten Banggai dengan luas Panen 5.384 ha menghasilkan produksi sebesar 26.602 Ton serta produktivitas sebesar 4,95 ton/ha. Selain itu dari tabel tersebut terlihat bahwa selain Kecamatan Masama ada bebeapa kecamatan yang merupakan sentra penghasil beras yaitu Kecamatan Toili (4,75 ton/ha), Kecamatan Toili Barat (4,75). Luas Panen, Produksi dan produktivitas Kecamatan Masama selama bebeapa tahun dapat dilihat pada Tabel berikut:

Tabel 3. Luas Panen, Produksi dan Produktivitas Tanaman Padi Sawah (Oryza sativa. L) Kecamatan Masama Tahun 2008-2011.

\begin{tabular}{cccc}
\hline Tahun & $\begin{array}{c}\text { Luas Panen } \\
(\mathrm{Ha})\end{array}$ & $\begin{array}{c}\text { Produksi } \\
(\text { Ton })\end{array}$ & $\begin{array}{c}\text { Produktivitas } \\
\text { (Ton / Ha) }\end{array}$ \\
\hline 2008 & 5.465 & $20.674,75$ & 3,78 \\
2009 & 5.522 & $21.577,70$ & 3,91 \\
2010 & 5.374 & $19.778,35$ & 3,68 \\
2011 & 5.399 & $21.889,60$ & 4,05 \\
\hline Jumlah & 21.760 & $83.920,40$ & 15,43 \\
\hline Rata-rata & 5.440 & $20.980,10$ & 3,86 \\
\hline
\end{tabular}

Sumber Data : BPS Kabupaten Banggai, 2012.

Tabel 3 terlihat bahwa tahun 2008 luas Panen 5.465 ha menghasilkan produksi 20.674,75 ton dan produktivitas sebesar 3,78 ton/ha. Pada tahun 2009 luas Panen 5.522 ha menghasilkan produksi 21.577,70 ton dan produktivitas sebesar 3,91 ton/ha. Tahun 2010 produksi tanaman padi sawah mengalami penurunan dengan luas Panen 5.374 ha menghasilkan produksi 19.778,35 ton dan produktivitas sebesar 3,68 ton/ha. Pada tahun 2011 tanaman padi sawah mengalami peningkatan dan merupakan jumlah tertinggi yaitu berjumlah 4,05 ton/ha, dengan produksinya sebesar 5.535 ton dengan luas panen sebanyak 1.118 ha

Desa Kospa Duwata Karya merupakan salah satu Desa pengahasil beras di Kecamatan Masama, dengan memperhatikan data luas panen, produksi dan berbagai hal potensi pendukung dan permasalahan di Desa Kospa Duwata Karya di Kecamatan Masama, maka perlu di adakan penelitian untuk mengetahui lebih lanjut tentang gambaran usaha Petani Padi Sawah (Oryza sativa. L) di Desa Kospa Duwata Karya Kecamatan Masama dan dapat dilihat pada beberapa Desa yang ada di Kecamatan Masama seperti pada Tabel 4 berikut. 


$\begin{array}{ll}\text { Volume } & : 04 \\ \text { Nomor } & : 02 \\ \text { Bulan } & : \text { Mei } \\ \text { Tahun } & : 2018 \\ \text { http } & : \text { //ejurnal.pps.ung.ac.id/index.php/AKSARA/index }\end{array}$

Tabel 4. Luas Panen, Produksi dan Produktivitas Tanaman Padi Sawah (Oryza sativa. L) di beberapa Desa di Kecamatan Masama, Tahun 2012.

\begin{tabular}{|c|c|c|c|c|}
\hline No & Tahun & $\begin{array}{l}\text { Luas Areal } \\
\text { (Ha) }\end{array}$ & $\begin{array}{l}\text { Produksi } \\
\text { (Ton) }\end{array}$ & $\begin{array}{c}\text { Produktivitas } \\
\text { (Ton / Ha) }\end{array}$ \\
\hline 1 & Tangeban & 309 & $1.369,58$ & 4,43 \\
\hline 2 & Serese & 158 & 701,46 & 4,44 \\
\hline 3 & Cemerlang & 115 & 510,55 & 4,44 \\
\hline 4 & Taugi & 205 & 910,12 & 4,44 \\
\hline 5 & Eteng & 970 & $4.087,05$ & 4,21 \\
\hline 6 & Padangon & 450 & $1.989,30$ & 4,42 \\
\hline 7 & Minang Andala & 705 & $3.117,88$ & 4,42 \\
\hline 8 & Ranga-Ranga & 105 & 463,66 & 4,42 \\
\hline 9 & Purwo Agung & 410 & $1.813,30$ & 4,42 \\
\hline 10 & Kembang Merta & 728 & $2.717,65$ & 3,74 \\
\hline 11 & Simpangan & 420 & $1.859,68$ & 4,43 \\
\hline 12 & Kospa Duwata Karya & 619 & $2.339,24$ & 3,78 \\
\hline 13 & Duwata Karya & 205 & 910,12 & 4,44 \\
\hline \multirow[t]{3}{*}{14} & Tompotika Makmur & - & - & - \\
\hline & Jumlah & 5399 & $22.789,59$ & 56,03 \\
\hline & Rata-rata & 385,64 & $1.627,83$ & 4,00 \\
\hline
\end{tabular}

Sumber Data : BPP Kec. Masama, 2012.

Tabel 4 diatas terlihat bahwa jumlah produktivitas tanaman Padi Sawah (Oryza sativa. L) di Desa Kospa Duwata Karya yaitu sebesar 3,78 ton/ha dengan luas panen sebanyak 619 ha dan jumlah produksi sebanyak 2.339,240 ton. Selain itu jumlah produksi dan produktivitas tanaman Padi Sawah di Desa Kospa Duwata Karya dan untuk lebih jelasnya dapat dilihat pada tabel 5 berikut.

Tabel 5. Luas Panen, Produksi dan Produktivitas Tanaman Padi Sawah (Oryza sativa. L) di Desa Kospa Duwata Karya, Tahun 2008-2011.

\begin{tabular}{cccc}
\hline Tahun & $\begin{array}{c}\text { Luas Panen } \\
(\mathrm{Ha})\end{array}$ & $\begin{array}{c}\text { Produksi } \\
\text { (Ton) }\end{array}$ & $\begin{array}{c}\text { Produktivitas } \\
\text { (Ton / Ha) }\end{array}$ \\
\hline 2008 & 785 & $2.967,00$ & 3,78 \\
2009 & 667 & $2.657,78$ & 3,98 \\
2010 & 600 & $2.156,25$ & 3,59 \\
2011 & 619 & $2.339,24$ & 3,78 \\
\hline Jumlah & 2.671 & $10.120,27$ & 15,14 \\
\hline Rata-rata & 667,75 & $2.530,07$ & 3,78 \\
\hline
\end{tabular}

Sumber Data : BPP Kec. Masama, 2012.

Tabel 5 diatas terlihat bahwa jumlah produksi pada tahun 2008 sebesar 2.967 ton dengan jumlah produktivitas sebesar 3,78, tahun 2009 dengan poduksi sebesar $2.657,78$ ton menghasilkan produktivitas 3,98. Pada tahun 2010 jumlah produksi tanaman padi sawah sebesar $2.156,25$ ton dengan luas panen 600 ha menghasilkan poduktivitas sebsar 3,59 dan pada tahun 2011 produktivitas tanaman Padi Sawah (Oryza sativa. L) di Desa Kospa Duwata Karya berjumlah 3,78 ton/ha dengan produksinya sebesar $2.339,24$ ton dengan luas panen 619 ha. 


$\begin{array}{ll}\text { Volume } & : 04 \\ \text { Nomor } & : 02 \\ \text { Bulan } & : \text { Mei } \\ \text { Tahun } & : 2018 \\ \text { http } & : / / \text { jurnal.pps.ung.ac.id/index.php/AKSARA/index }\end{array}$

Naiknya produktivitas pada umumnya bisa dimungkinkan karena adanya penggunaan berbagai faktor produksi yang cukup efisien, namun demikian tetap diakui bahwa tingginya produksi dan produktivitas suatu usahatani tidak selamanya akan diikuti dengan besarnya pendapatan yang diperoleh petani dari hasil usahataninya. Hal ini disebabkan karena besar kecilnya pendapatan dari suatu usahatani sangat dipengaruhi oleh jumlah dan tingkat harga faktor produksi yang digunakan, harga jual produksi usahatani yang bersangkutan maupun banyaknya jumlah permintaan dari konsumen.

Upaya Peningkatan pendapatan petani dari hasil usahatani, secara umum sangat tergantung pada besarnya jumlah biaya produksi, terutama untuk pembelian sarana produksi seperti benih, pupuk, pestisida, serta biaya tenaga kerja. Hal ini akan sangat berpengaruh terhadap besar kecilnya penerimaan maupun pendapatan yang diperoleh petani dari hasi usahataninya.

Berdasarkan uraian tersebut, maka dalam upaya peningkatan pendapatan petani, khususnya yang diperoleh dari hasil usahatani padi sawah di Desa Kospa Duwata Karya masih sangat diperlukan berbagai informasi melalui penelitian yang dapat mengungkapkan besarnya pengaruh produksi fisik, harga faktor-faktor produksi, besarnya biaya produksi serta harga jual produksi usahatani yang bersangkutan, terhadap besarnya penerimaan maupun pendapatan serta keuntungan yang diperoleh petani dari hasil usahatani padi sawah di Desa Kospa Duwata Karya Kecamatan Masama Kabupaten Banggai.

\section{METODE PENELITIAN}

Lokasi penelitian ini di tentukan secara sengaja (Purposive) dengan pertimbangan bahwa Usahatani Padi Sawah masih cerah untuk di teliti. Penelitian ini dilaksanakan di Desa Kospa Duwata Karya Pada Bulan November-Desember 2012.

\section{Populasi Dan Sampel}

Penentuan Populasi dengan menggunakan Metode sampel acak bertingkat (Stratifikasi Random Sampling) yaitu Dari populasi petani (Responden) sebanyak 255 orang (KK) yang di tatapkan menjadi sampel sebanyak 26 orang petani atau 10 $\%$, Dengan pertimbangan untuk mewakili populasi petani yang berusahatani Padi Sawah (Oryza sativa. L) di Desa Kospa Duwata Karya Kecamatan Masama dengan rincian:

a. 6 orang petani yang luas lahan $0,50 \mathrm{Ha}$

b. 13 orang petani yang luas lahan $1,00 \mathrm{Ha}$

c. 3 orang petani yang luas lahan $1,5 \mathrm{Ha}$

d. 4 orang petani yang luas lahan $2,00 \mathrm{Ha}$

\section{Jenis dan sumber data.}

Penelitian ini di laksanakan menggunakan data primer yang di peroleh lansung dari petani (Responden) Padi Sawah (Oryza sativa. L) dengan cara Obsevasi langsung dan data sekunder di peroleh dari Literatur-literatur, dan Kantor instansi terkait di Kecamatan Masama Kabupaten Banggai.

\section{Metode Pengumpulan Data.}




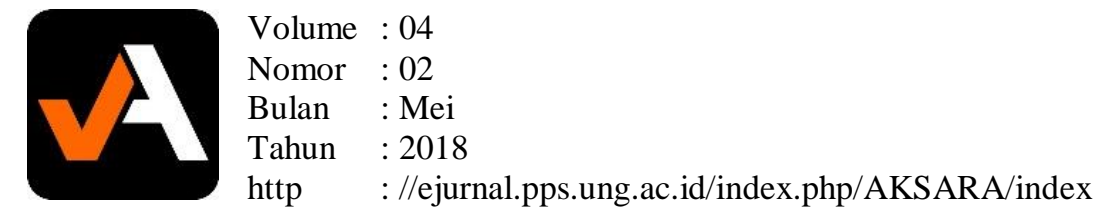

Pengumpulan data penelitian ini dengan menggunakan cara:

a. Wawancara dengan alat bantu kuisioner berupa daftar pertanyaan.

b. Studi lapangan dan data instansi terkait.

\section{Metode Analisis Data}

Analisis yang digunakan dalam penelitan ini yaitu analisis pendapatan (Soekartawi, 2006)

$$
\begin{aligned}
& P d=T R-T C \\
& T R=P x Q \\
& T C=F C+V C
\end{aligned}
$$

Secara teoritis analisis titik pulang pokok (TPP) dapat dibedakan menjadi TPP Produksi (kg) dan TPP Penerimaan (Rp), masing-masing dapat dihitung dengan menggunakan rumus sebagai berikut:

(1) TPP Produksi (Q) (kg)

$$
=\frac{F C}{P-A V C}
$$

(2) TPP Penerimaan (TR) (Rp)

$$
=\frac{\text { TFC } \cdot \mathrm{P}}{\mathrm{P} \cdot \mathrm{AVC}}
$$

TFC

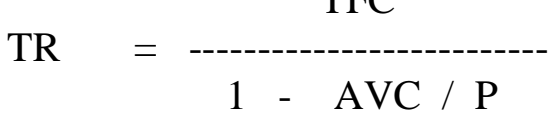

(Suratiyah, 2006).

TPP Penerimaan disederhanakan menjadi:

$$
\mathbf{T R}=\mathbf{P} \cdot \mathbf{Q}
$$

(Soekartawi, 2003)

\section{Keterangan:}

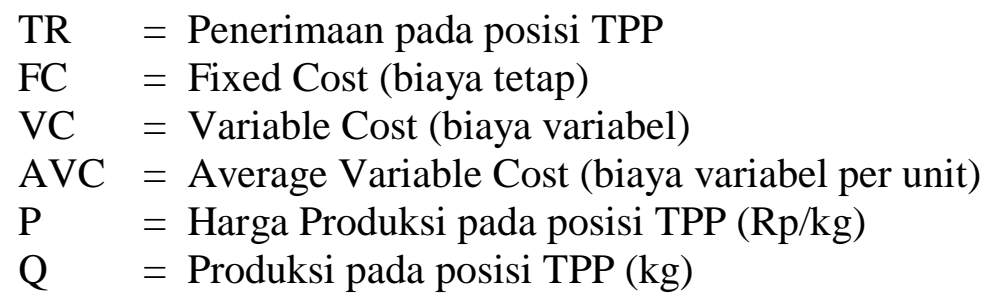

\section{Konsep Oprasional}

Adapun yang menjadi konsep operasional yaitu sebagai berikut :

a. Biaya produksi adalah semua pengeluaran yang digunakan untuk melakukan Usahatani yang terdiri dari biaya tetap dan biaya variabel dinyatakan dalam rupiah (Rp).

b. Biaya tetap adalah biaya yang dikeluarkan tanpa di pengaruhi oleh besar kecilnya produksi seperti pajak dan penyusutan yang dinyatakan dalam rupiah $(\mathrm{Rp})$. 


$\begin{array}{ll}\text { Volume } & : 04 \\ \text { Nomor } & : 02 \\ \text { Bulan } & : \text { Mei } \\ \text { Tahun } & : 2018 \\ \text { http } & : \text { //ejurnal.pps.ung.ac.id/index.php/AKSARA/index }\end{array}$

c. Biaya variabel adalah biaya yang dikeluarkan yang tergantung dari besar kecilnya produksi dinyatakan dalam Rupiah (Rp).

d. Produksi adalah hasil yang diperoleh setiap harinya yang dinyatakan dalam $(\mathrm{Kg})$.

e. Harga produksi adalah harga yang berlaku ditingkat Petani padi yang dinyatakan dalam rupiah (Rp).

f. Penerimaan adalah hasil kali antara jumlah produksi usahatani dengan harga yang dinyatakan dalam rupiah (Rp).

g. Pendapatan adalah selisih antara total penerimaan (TR) dengan total biaya (TC) yang dinyatakan dalam rupiah ( $\mathrm{Rp})$.

h. Titik Pulang Pokok adalah keadaan suatu usaha ketika tidak memperoleh laba dan tidak memperoleh rugi.

\section{HASIL DAN PEMBAHASAN}

\section{Penggunaan Faktor Produksi dan Input Produksi}

\section{1) Luas Lahan}

Lahan sebagai media tumbuh tanaman merupakan faktor produksi yang sangat penting dalam pengelolaan usahatani. Secara umum dapat dinyatakan, bahwa semakin luas lahan usahatani, semakin tinggi pula produksi yang dihasilkan, demikian sebaliknya semakin sempit lahan usahatani, semakin rendah pula produksi yang dihasilkan.

Sesuai dengan data yang diperoleh, diketahui bahwa luas lahan yang digarap oleh petani responden dalam usahatani Padi Sawah di Desa Kospa Duwata Karya, relatif homogen, yakni rata-rata seluas 1,10 ha, dari variasi luas lahan yang berkisar antara 0,50 ha $-2,00$ ha. Berdasarkan data luas lahan seperti yang tercantum pada Lampiran 1, maka secara rinci luas lahan yang digunakan oleh petani responden dalam usahatani Padi Sawah di Desa Kospa Duwata Karya dapat diklasifikasikan seperti yang tercantum dalam Tabel 12 .

Tabel 5. Luas Lahan Petani Responden Padi Sawah di Desa Kospa Duwata Karya, Tahun 2012.

\begin{tabular}{cccc}
\hline No & $\begin{array}{c}\text { Luas Lahan } \\
\text { (ha) }\end{array}$ & $\begin{array}{c}\text { Petani Responden } \\
\text { (orang) }\end{array}$ & $\begin{array}{c}\text { Persentase } \\
(\%)\end{array}$ \\
\hline 1 & $0,50-1,00$ & 19 & 73,08 \\
2 & $1,50-2,00$ & 7 & 26,92 \\
\hline & Jumlah & 26 & 100,00 \\
\hline
\end{tabular}

Sumber : Diolah dari data primer, 2012.

Data pada Tabel 5 menunjukkan, bahwa sebagian besar petani responden $(76,67 \%)$ hanya mengerjakan lahan yang luasnya berkisar antara $0,50-1,00$ ha, selanjutnya diikuti oleh responden yang mengelola lahan usahataninya dengan luas antara 1,25 ha - 2,00 ha, yaitu sebanyak 7 orang (23,33\%). Hal ini dapat difahami mengingat Desa Kospa Duwata Karya merupakan salah satu desa bekas daerah transmigrasi yang ada di wilayah Kabupaten Banggai.

Ditinjau dari luas lahan usahatani yang dikelola, maka pada dasarnya dapat dinyatakan, bahwa lahan usahatani tersebut relatif cukup luas, namun demikian 


$\begin{array}{ll}\text { Volume } & : 04 \\ \text { Nomor } & : 02 \\ \text { Bulan } & : \text { Mei } \\ \text { Tahun } & : 2018 \\ \text { http } & : / / \text { jurnal.pps.ung.ac.id/index.php/AKSARA/index }\end{array}$

untuk memperoleh pendapatan usahatani yang tinggi, masih sangat tergantung atas jenis usahatani yang diusahakan serta faktor-faktor produksi lainnya, seperti penggunaan benih, pupuk, maupun tenaga kerja.

\section{2) Penggunaan Benih}

Benih merupakan salah satu faktor yang menentukan keberhasilan usahatani yang bersangkutan, selain itu penggunaan benih yang berkualitas baik, merupakan hal penting yang perlu mendapat perhatian dalam upaya peningkatan produksi.

Benih Padi Sawah yang digunakan oleh responden pada umumnya adalah varietas "Ciherang" yang lebih banyak diusahakan sendiri oleh para petani dari hasil panen sebelumnya. Selanjutnya sesuai dengan data penggunaan benih seperti yang tercantum pada Lampiran 3 diketahui, bahwa pada lahan usahatani rata-rata seluas 1,10 ha benih Padi Sawah yang digunakan petani adalah sebanyak $55 \mathrm{~kg}$.

Jumlah benih yang digunakan tersebut ternyata sedikit lebih banyak, jika dibandingkan dengan penggunaan benih yang direkomendasikan secara nasional, yaitu sebanyak $40 \mathrm{~kg}$ per ha (Ditjen Hortikultura, Departemen Pertanian, 2007).

Selanjutnya jika rata-rata harga benih seperti yang tercantum pada Lampiran 3 adalah Rp. 5.000,- maka rata-rata biaya penggunaan benih petani responden mencapai sebesar Rp. 276.923/1,10 ha atau rata-rata sebesar Rp. 251.748/ha.

\section{3) Penggunaan Pupuk}

Pupuk merupakan salah satu faktor produksi yang dapat meningkatkan produksi sehubungan dengan tersedianya unsur hara dalam tanah untuk mendukung pertumbuhan dan produksi tanaman. Jenis pupuk yang digunakan responden petani Padi Sawah di Desa Kospa Duwata Karya yaitu pupuk Urea, SP36, NPK, Pupuk kandang dan pupuk cair (PPC).

Penggunaan beberapa jenis pupuk tersebut, masing-masing adalah sebagai berikut: (1) untuk Urea rata-rata sebanyak $144 \mathrm{~kg} / \mathrm{ha}$, dan jika harga pupuk Urea rata-rata Rp. 1.800,- per kg, maka pengeluaran untuk pupuk Urea ini mencapai Rp. 236.014,- per ha. (2) pupuk SP36 rata-rata sebanyak 30kg/ha, dan jika harga pupuk SP36 rata-rata Rp. 2.182,- per $\mathrm{kg}$, maka pengeluaran untuk pupuk SP36 ini mencapai Rp. 71.329,-- per ha. (3) pupuk NPK rata-rata sebanyak $173 \mathrm{~kg} / \mathrm{ha}$, dan jika harga pupuk NPK rata-rata Rp. 2.273,- per kg, maka pengeluaran untuk pupuk NPK ini mencapai Rp432.692,- per ha. (4) pupuk PPC rata-rata sebanyak 1,71 liter/ha, dengan harga rata-rata sebesar Rp. 22.727/liter, maka rata-rata pengeluaran untuk pupuk PPC ini mencapai Rp. 42.832 liter/ha. (5) pupuk kandang rata-rata sebanyak 0,70 kg/ha, dan jika harga pupuk kandang rata-rata $\mathrm{Rp} .9 .091$,- per kg, maka pengeluaran untuk pupuk kandang ini mencapai $\quad$ Rp. 6.993,- per ha, sehingga total pengeluaran untuk pembelian pupuk rata-rata mencapai $\mathrm{Rp}$. 789.860/ha.

\section{4). Penggunaan Tenaga Kerja}

Salah satu pendukung keberhasilan suatu usahatani adalah penggunaan tenaga kerja yang efektif serta memiliki kemampuan dan ketrampilan yang cukup memadai. Secara umum penggunaan tenaga kerja sangat tergantung pada jenis pekerjaan yang terdapat dalam setiap usahatani. 


$\begin{array}{ll}\text { Volume } & : 04 \\ \text { Nomor } & : 02 \\ \text { Bulan } & : \text { Mei } \\ \text { Tahun } & : 2018 \\ \text { http } & : / / \text { jurnal.pps.ung.ac.id/index.php/AKSARA/index }\end{array}$

Sesuai dengan data penggunaan tenaga kerja yang diperoleh dan tercantum pada Lampiran 7, diketahui bahwa tenaga kerja yang digunakan petani responden dalam usahatani Padi Sawah di Desa Kospa Duwata Karya, meliputi berbagai jenis pekerjaan: Penyemaian, penanaman, pemupukan, penyiangan, pemupukan, Penyemprotan, Panen, pengangkuta hasil (panen) serta Pengeringan Semua jenis pekerjaan tersebut diselesaikan dengan menggunakan tenaga kerja rata-rata sebanyak 49,55 HOK per ha, dan dengan rata-rata upah sebesar Rp. 50.000/hari, maka total biaya tenaga kerja yang harus dikeluarkan oleh responden petani Padi Sawah di Desa Kospa Duwata Karya ini rata-rata mencapai Rp. 2.445.804 per ha.

\subsection{Analisis Pendapatan Usahatani}

Analisis pendapatan dimaksudkan untuk mengetahui besarnya pendapatan responden petani Padi Sawah dalam usahatani Padi Sawah di Desa Kospa Duwata Karya, dengan cara menghitung selisih antara jumlah penerimaan dengan biaya tetap dan biaya variabel.

\section{1) Penerimaan Usahatani (TR)}

Penerimaan dalam struktur usahatani adalah perkalian antara produksi yang diperoleh dengan harga jual, sehingga penerimaan ditentukan oleh besar kecilnya produksi yang dihasilkan serta harga dari produk tersebut.

Sesuai dengan hasil analisis yang tercantum pada Lampiran 11 diketahui, bahwa pada rata-rata lahan petani seluas 1,10 ha petani responden Padi Sawah di Desa Kospa Duwata Karya menghasilkan produksi rata-rata sebanyak $2.473 \mathrm{~kg}$, atau kurang lebih sebesar $2.247 \mathrm{~kg} / \mathrm{ha}$. Selanjutnya dengan harga jual rata-rata Rp. $5.909 / \mathrm{kg}$, maka penerimaan petani responden rata-rata akan mencapai $\mathrm{Rp}$. 14.611.364 per ha.

\section{2) . Total Biaya Produksi Usahatani (TC)}

Total biaya produksi secara sederhana dirumuskan sebagai penjumlahan dari biaya tetap dan biaya variabel, sehingga diperoleh hasil perhitungan seperti yang terantum pada Lampiran 11, dimana diketahui biaya tetap rata-rata mencapai sebesar Rp. 259.825/ha/MT, biaya variabel sebesar Rp. 6.131.315/ha/MT, sehingga total biaya produksi yang harus dikeluarkan oleh petani Padi Sawah di Desa Kospa Duwata Karya ini rata-rata mencapai Rp. 6.391.140/ha/MT.

\section{3). Pendapatan Usahatani $(\pi)$}

Ukuran yang digunakan untuk menetapkan besarnya pendapatan yang diperoleh petani dari suatu usahatani, adalah selisih antara penerimaan dengan jumlah pengeluaran atau total biaya, yang terdiri atas biaya tetap dan biaya variabel. Selengkapnya hasil analisis data pendapatan usahatani Padi Sawah di Desa Kospa Duwata Karya ini dicantumkan dalam Tabel 13. 


$\begin{array}{ll}\text { Volume } & : 04 \\ \text { Nomor } & : 02 \\ \text { Bulan } & : \text { Mei } \\ \text { Tahun } & : 2018 \\ \text { http } & : / / \text { jurnal.pps.ung.ac.id/index.php/AKSARA/index }\end{array}$

Tabel 6. Rata-rata Pendapatan Usahatani Padi Sawah (per ha) di Desa Kospa Duwata Karya Kecamatan Masama Kabupaten Banggai, 2012

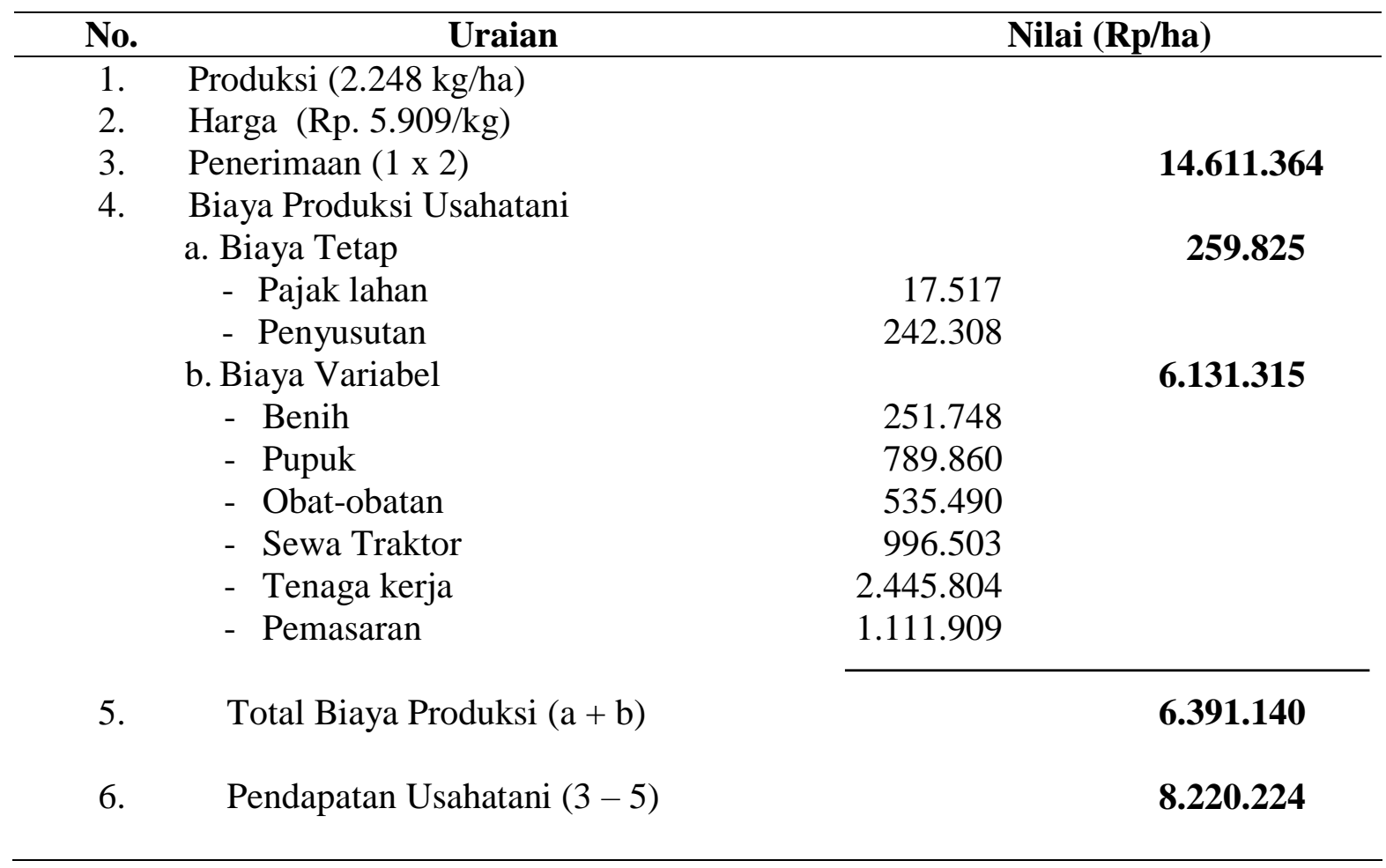

Sumber : Diolah dari data primer, 2012

Data yang tercantum dalam Tabel 6 tersebut menunjukkan, bahwa dengan rata-rata biaya produksi usahatani sebesar Rp. 6.391.140/ha/MT yang terdiri atas biaya tetap sebesar Rp. 259.825 dan biaya variabel sebesar Rp. 6.131.315, diperoleh hasil produksi sebanyak $2.248 \mathrm{~kg}$ dan dengan rata-rata harga jual sebesar Rp. 5.909/kg, diperoleh penerimaan rata-rata sebesar Rp. 14.611.364, sehingga diperoleh pendapatan usahatani rata-rata sebesar Rp. 8.220.224/ha/MT.

\subsection{Analisis Titik Pulang Pokok}

Menurut Ahyari (1986) yang dimaksud dengan titik pulang pokok adalah suatu titik yang menunjukkan keadaan total penerimaan sama dengan total biaya. Analisis titik pulang pokok merupakan salah satu cara yang dilakukan untuk mengetahui keadaan suatu usaha pada periode tertentu, apakah berada dalam posisi menguntungkan atau berada pada posisi menderita kerugian.

Sesuai dengan data yang diperoleh dari dari para petani responden, tentang perhitungan rata-rata biaya tetap dan biaya variabel maka Berdasarkan data hasil analisis usahatani Padi Sawah di Desa Kospa Duwata Karya, seperti yang tercantum pada Tabel 13, diperoleh hasil perhitungan titik pulang pokok (TPP) sebagai berikut:

Diketahui: 
- Produksi (Q)

: $2.248 \mathrm{~kg} / \mathrm{ha}$

- Harga (P)

:Rp. $5.909 / \mathrm{kg}$

- Biaya tetap (FC)

: Rp. 259.825

- Biaya variabel (VC) : Rp. 6.131.315

- AVC (VC/Q)

a) Volume produksi pada titik pulang pokok dapat dihitung dengan rumus :

$$
\begin{aligned}
\boldsymbol{Q} & =\frac{\boldsymbol{T F C}}{\boldsymbol{P}-\boldsymbol{A} \boldsymbol{V C}} \quad \text { (Suratiyah, K., 2006). } \\
& =\frac{259.825}{5.909-2.728}=81,67 \mathrm{~kg} \\
& =\frac{259.825}{3.182}=8 .
\end{aligned}
$$

Jadi volume penjualan pada titik pulang pokok untuk produksi fisik Padi Sawah di Desa Kospa Duwata Karya adalah sejumlah 81,67 kg, dengan harga jual Rp. 5.909,- per kg.

b) TPP Penerimaan (TR) (Rp)

$$
=\frac{\mathrm{TFC} \cdot \mathrm{P}}{\mathrm{P} \cdot \mathrm{AVC}}
$$

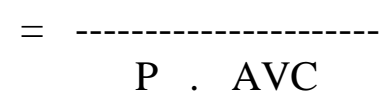

$$
\begin{aligned}
\mathrm{TR}= & \text { TFC } \\
& 1-\text { AVC / P } \\
\mathrm{TR}= & 259.825 \\
& 1-2.728 / 5.909 \\
= & 482.578
\end{aligned}
$$

Hasil perhitungan menunjukkan, bahwa pada rata-rata lahan usahatani Padi Sawah seluas 1,10 ha, para petani responden akan mencapai titik pulang pokok atau tidak untung dan tidak rugi, jika penerimaan yang diperoleh mencapai Rp. 482.578,- per MT, atau produksi rata-rata mencapai $81,67 \mathrm{~kg}$, dengan harga jual Rp. $5.909 / \mathrm{kg}$, atau jika produksi mencapai $81,67 \mathrm{~kg}$, maka petani mencapai titik pulang pokok, pada tingkat harga sebesar Rp. $5.909 / \mathrm{kg}$.

Berdasarkan pemahaman atas hasil analisis tersebut, maka petani Padi Sawah di Desa Kospa Duwata Karya dapat melakukan perencanaan produksi serta biaya produksi yang harus dikeluarkan untuk mencapai tingkat keuntungan tetentu. 


$\begin{array}{ll}\text { Volume } & : 04 \\ \text { Nomor } & : 02 \\ \text { Bulan } & : \text { Mei } \\ \text { Tahun } & : 2018 \\ \text { http } & : / / \text { jurnal.pps.ung.ac.id/index.php/AKSARA/index }\end{array}$

\section{KESIMPULAN}

Hasil penelitian ini memberi kesimpulan sebagai berikut

1 Volume penjualan pada titik pulang pokok untuk produksi fisik Padi Sawah di Desa Kospa Duwata Karya adalah sejumlah 81,67 kg, dengan harga jual Rp. 5.909 ,- per $\mathrm{kg}$.

2 Hasil perhitungan menunjukkan, bahwa pada rata-rata lahan usahatani Padi Sawah seluas 1,10 ha, para petani responden akan mencapai titik pulang pokok atau tidak untung dan tidak rugi, jika penerimaan yang diperoleh mencapai $\mathrm{Rp}$. 482.578 ,- per MT, atau produksi rata-rata mencapai $81,67 \mathrm{~kg}$.

\section{DAFTAR PUSTAKA}

AAK, 2005. Analisis Kelayakan Finansial usaha jasa Penggilingan padi, Skripsi Faperta Untika, Luwuk.

Adiwilaga, 1994. Analisis Pendapatan. Penebar Swadaya, Jakarta

BPS. Kecamatan dalam angka, Kabupaten Banggai, 2011.

BPP, 2011. Kecamatan Masama dalam angka, 2011.

Fadholi Hernanto, 1993. Ilmu Usahatani, Penebar Swadaya, Jakarta.

Ken Suratiyah, 2009. Ilmu Usahatani. Penebar Swadaya Wisma Hijau, Jl. Raya Bogor Km 30, Mekar Sari, Jakarta.

Mohar Daniel. Ir. Ms. 2001. Pengantar Ekonomi Pertanian. PT. Bumi Aksara, Jakarta.

Munawir, 2002. Analisa Laporan Keuangan. Liberty. Yokyakarta. Prawirokusumo, 1990. Bertanam Padi .Penebar Swadaya, Jakarta Rahim Abdullah. 2004. Pengantar Teori dan Kasus Ekonomi Pertanian, Jakarta Soekartawi,1995. Analisis Usahatani, Universitas Indonesia Press, Jakarta Soekartawi, 2003. Teori Ekonomi Produksi. PT. Raja Grafindo Pesada, Jakarta. Soekartawi, 2006. Usahatani, Universitas Indonesia Press, Jakarta Supriyono, 2000 Padi. Penebar Swadaya . Jakarta Syafrizal helmi, 2009. http://shelmi.wordpress.com/2009/03/30/break-even-point

Seyong, 2011 http://seyong 2011.blogspot.com/business-management.html

Tohir, K.A, 1983. Seuntai Pengetahuan Tentang Usahatani Indonesia. Bina Aksara,Jakarta 